\title{
KOMIK STRIP UNTUK MEDIA PEMBELAJARAN MATEMATIKA \\ KELAS V SEKOLAH DASAR
}

\author{
Khafidzoh Asfihani $^{1}$, Ahmad Nashir Tsalatsa ${ }^{2}$, Aries Tika Damayani ${ }^{3}$ \\ hani.asfihani87@gmail.com \\ ${ }^{123}$ Universitas PGRI Semarang
}

\begin{abstract}
ABSTRAK
Latar belakang penelitian ini yaitu kurangnya ketertarikan peserta didik pada pembelajaran matematika karena peserta didik menganggap pembelajaran matematika sulit. Tujuan penelitian ini yaitu mengembangkan media pembelajaran komik strip untuk memberikan inovasi terbaru untuk pembelajaran matematika. Media pembelajaran ini dikembangkan dari komik yang mempunyai alur disesuaikan dengan materi agar bisa menjadi alternatif media pembelajaran yang inovatif dan tentunya melalui tahap pengujian terlebih dahulu.. Data yang diperoleh dalam penelitian ini yaitu data dari ahli media, ahli materi dan data dari hasil uji coba produk. Instrumen data dalam penelitian ini yaitu angket dan soal. Hasil dari angket kemudian dianalisis secara deskriptif. Validasi dari ahli media 1 tahap 1 sebesar 83,33\%, validasi ahli media 1 tahap 2 sebesar 93,33\%, Selanjutnya hasil analisis data dari validasi ahli materi 1 tahap 1 sebesar 53,84\%, validasi ahli materi 1 tahap 2 sebesar $96,15 \%$, validasi ahli materi 2 tahap 1 sebesar 92,30\%, validasi ahli materi 2 tahap 2 sebesar 98,07\%. Hasil tanggapan peserta didik sebesar $100 \%$ dan hasil tanggapan guru sebesar $98,33 \%$. Hal ini dapat menunjukan bahwa komik strip telah berhasil dalam pengembanganya media pembelajaran ini juga sangat layak digunakan.
\end{abstract}

Kata kunci: komik, komik strip, media komik, matematka, media pembelajaran matematika

PENDAHULUAN

Sugiyono

$(2015: 297)$

mengemukakan bahwa Research and

Development adalah metode yang

digunakan untuk membuat atau

menghasilkan produk baru dan

mengembangkan produk tertentu.
Plomp (2013) dalam Prahmana

(2017:13) mengemukakan Design

Research adalah suatu pembelajaran

sistematis yang dimulai dari rancangan

awal, pengembangan dan

mengevaluasi seluruh intervensi yang

berhubungan dengan pendidikan,

seperti program, proses belajar,

lingkungan belajar, bahan ajar, produk 
pembelajaran, dan sistem pembelajaran.

Berdasarkan

Peraturan Pemerintah Republik Indonesia Nomor 19 Tahun 2005 tentang Standar Nasional Pendidikan pada Bab IV mengenai Standar Proses Pasal 19 Ayat 1 menyatakan bahwa proses pembelajaran pada satuan pendidikan diselenggarakan secara interaktif, inspiratif, menyenangkan, menantang, memotivasi peserta didik untuk berpartisipasi aktif, serta memberikan ruang yang cukup bagi prakarsa, kreativitas, dan kemandirian sesuai dengan bakat, minat, dan perkembangan fisik serta psikologis peserta didik. Menurut UU No. 20 Tahun 2003 tentang Sistem Pendidikan Nasional Pasal 1, menyebutkan bahwa pendidikan adalah usaha sadar dan terencana untuk mewujudkan suasana belajar dan proses pembelajaran agar peserta didik secara aktif mengembangkan potensi dirinya untuk memiliki kekuatan spiritual keagamaan, pengendalian diri, kepribadian, kecerdasan, akhlak mulia, serta keterampilan yang diperlukan dirinya, masyarakat, bangsa dan negara.

"Pembelajaran adalah kegiatan guru secara terprogram dalam desain instruksional untuk membuat peserta didik belajar aktif, yang menekankan pada penyediaan sumber belajar". Dimyati (2006) dalam Ahmad Susanto (2013:186)

Pembelajaran kelas V sekolah dasar belum sepenuhnya menggunakan media, hal ini nampak pada saat pembelajaran peserta didik menunjukkan sikap yang kurang antusias dan kurang berpusatnya perhatian terhadap guru. Menurut Gagne dan Briggs (1975) dalam Arsyad (2017:4) media pembelajaran meliputi alat yang secara fisik digunakan untuk menyampaikan isi materi pengajaran, yang terdiri dari antara lain buku, tape recorder, kaset, video camera, video recorder, film, slide (gambar bingkai), foto, gambar, grafik, televisi, dan computer.

Media belajar merupakan suatu alat peraga untuk memudahkan guru dalam menerangkan pembelajaran kepada peserta didik. 
Dalam pembelajaran matematika guru dapat menggunakan media pembelajaran untuk membuat peserta didik memperhatikan guru dan pembelajaran, serta dapat menambah pengetahuan dan kreatifitas dalam penggunaan media tersebut. Penelitian ini bertujuan untuk pengembangan media komik strip pada pembelajaran matematika materi kecepatan, jarak, dan waktu kelas V sekolah dasar. Diharapkan media ini mampu menjadi inspirasi dan inovasi terbaru untuk mengembangkan media pembelajaran untuk kelangsungan pembelajaran di kelas yang aktif dan kreatif.

Menurut Daryanto (2016:146) kelebihan komik sebagai media pembelajaran, yakni komik mengandung unsur visual dan cerita yang kuat. Ekspresi yang divisualisasikan membuat pembaca terlibat secara emosional sehingga membuat pembaca untuk terus membacanya hingga selesai.

Gumelar (2011:7) mengemukakan komik adalah urutan gambar-gambar yang ditata sesuai tujuan dan filosofi pembuatannya sehingga pesan cerita tersampaikan, komik cenderung diberi lettering yang diperlukan sesuai dengan kebutuhan.

Gumelar (2011 : 92-197) Untuk membuat komik secara garis besar terbagi menjadi 3 teknik, yaitu teknik tradisional, teknik hybrid, teknik digital.

Dari hasil wawancara ketiga SD tersebut, maka peneliti menyimpulkan bahwa masalah yang dihadapi guru kelas V sama, yaitu kurang antusisanya peserta didik terhadap mata pelajaran matematika, kurangnya penggunaan media yang interaktif, media yang digunakan guru antara lain, balok kayu, kertas dan benda-benda konkrit yang berada di sekitar sekolah.

Menanggapi permasalahan tersebut, peneliti berupaya untuk mencari inovasi agar peserta didik kelas $\mathrm{V}$ sekolah dasar antusias dalam mata pelajaran matematika. Inovasi tersebut antara lain membuat media pembelajaran yang menarik dan dapat meningkatkan antusias peserta didik pada mata pelajaran matematika, serta 
dapat membuat peserta didik lebih aktif dan fokus pada penjelasan guru.

Diana Lela Novitasari Universitas Negeri Semarang (2016) dalam skripsi yang berjudul “ Pengembangan Media Komik Cerita Anak untuk Meningkatkan Keterampilan Menulis Narasi Peserta didik Kelas IV SDN 1 Ngawen Kabupaten Blora" membuktikan bahwa dilihat dari hasil analisis pada validasi ahli materi dan ahli media mendapatkan $89.50 \%$ dan dari hasil analisis kebahasaan $80 \%$, dan validasi penyajian presentase didapatkan $89.50 \%$, hal ini menunjukkan bahwa media pembelajaran matematika komik cerita anak dapat digunakan untuk mengembangkan aktivitas peserta didik dalam pembelajaran menulis narasi.

\section{METODE PENELITIAN}

Penelitian yang dilakukan adalah penelitian dan pengembangan tentang media pembelajaran komik strip pada pembelajaran matematika kelas V materi kecepatan, jarak dan waktu di sekolah dasar. Penelitian ini dilakukan karena peneliti akan mengembangkan produk media pembelajaran. Media pembelajaran ini dikembangkan dari komik yang mempunyai alur disesuaikan dengan materi agar bisa menjadi alternatif media pembelajaran yang inovatif dan tentunya melalui tahap pengujian terlebih dahulu. Penelitian ini berfokus pada dapat digunakan atau tidak media pembelajaran komik strip pada pembelajaran matematika kelas $\mathrm{V}$ materi kecepatan, jarak dan waktu.

\section{HASIL DAN PEMBAHASAN}

\section{Hasil Penelitian}

Awal penelitian ini yaitu dengan dilakukannya validasi desain. Validasi desain adalah tahap yang diperlukan untuk mengetahui kelebihan dan kelemahan dari media pembelajaran komik strip materi kecepatan, jarak dan waktu, serta untuk mengetahui hal yang masih kurang dan perlu ditambahkan sebelum diujikan. Validator yang memvalidasi media dan materi media pembelajaran komik strip 
materi kecepatan, jarak dan waktu. Validator materi dan media pembelajaran merupakan Dosen PGSD dan Guru Sekolah Dasar yang berkompeten. Pengujian media pembelajaran dilakukan ahli yang menguasai bidang media pembelajaran. Validasi oleh dosen ahli media dari keseluruhan aspek 1 , aspek 2 , aspek 3, aspek 4, dan aspek 5 dilakukan dua kali validasi. Berdasarkan hasil validasi dari validator ahli media didapatkan hasil berikut :

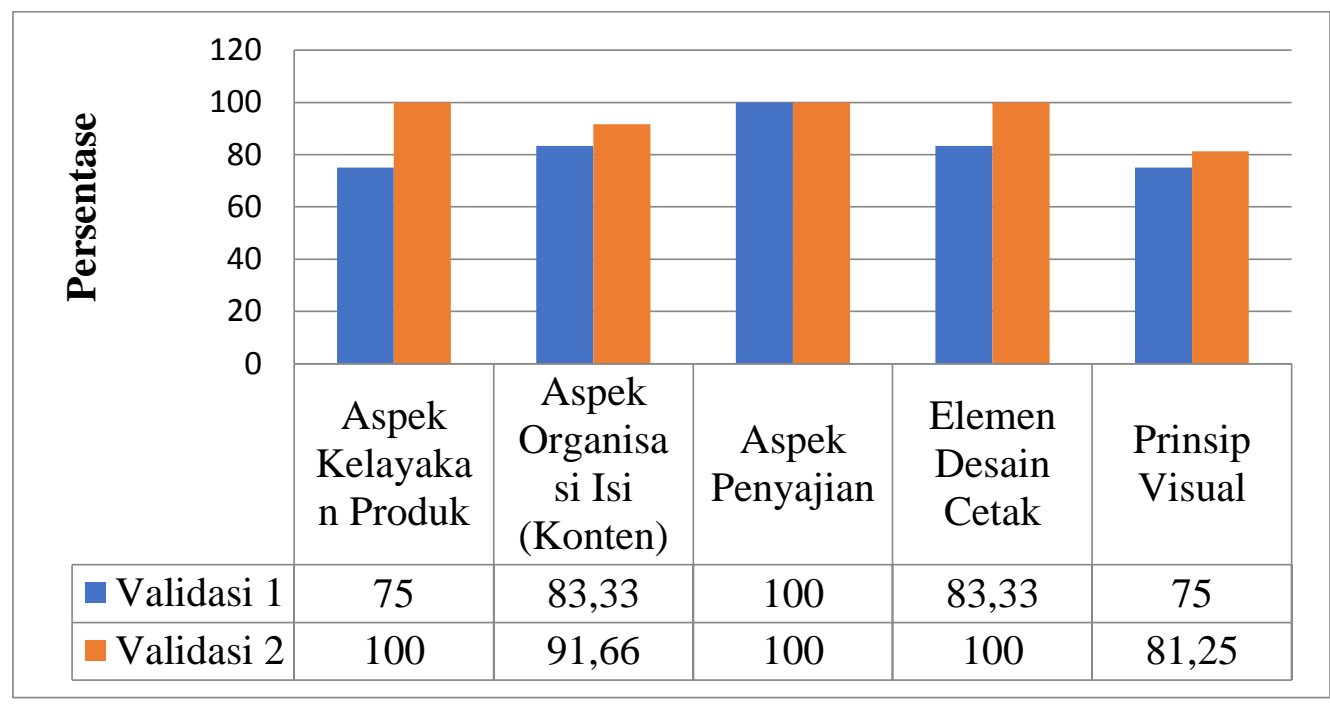

Gambar 1. Diagram Batang Tingkat Penilaian Media Pembelajaran Komik Strip oleh Dosen Validator Pertama Ahli Media Validasi Pertama Dan Kedua

Kemudian dilanjutkan dengan validasi oleh dosen ahli materi validator pertama dari keseluruhan aspek 1 , aspek 2 , aspek 3 , aspek 4 , dan aspek 5 dilakukan dua kali validasi. Berdasarkan hasil validasi dari validator ahli materi pertama didapatkan hasil berikut: 


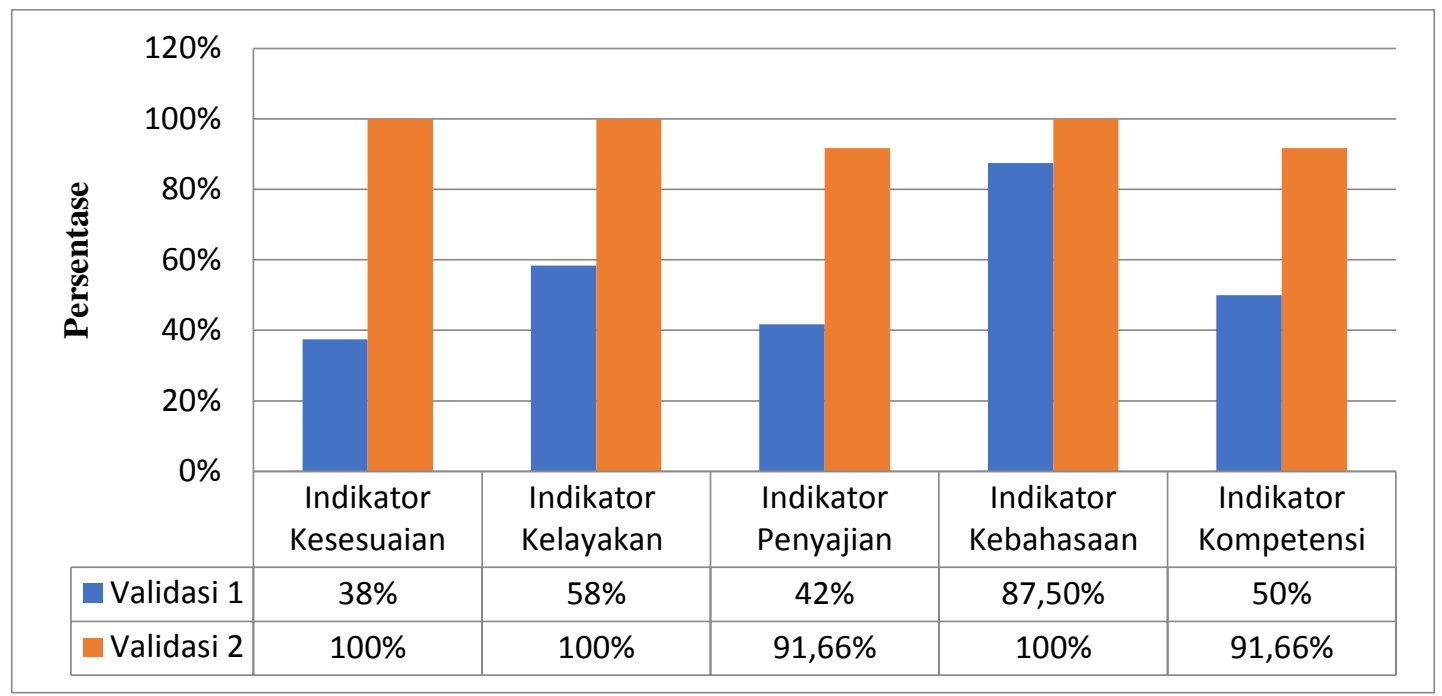

Gambar 2. Diagram Batang Tingkat Penilaian Media Pembelajaran Komik Strip oleh Dosen Validator Pertama

Selanjutnya validator ahli materi yang kedua untuk media pembelajaran komik strip dari keseluruhan aspek 1, aspek 2, aspek 3, aspek 4, dan aspek 5 dilakukan dua kali validasi. Berdasarkan hasil validasi dari validator ahli materi kedua didapatkan hasil sebagai berikut:

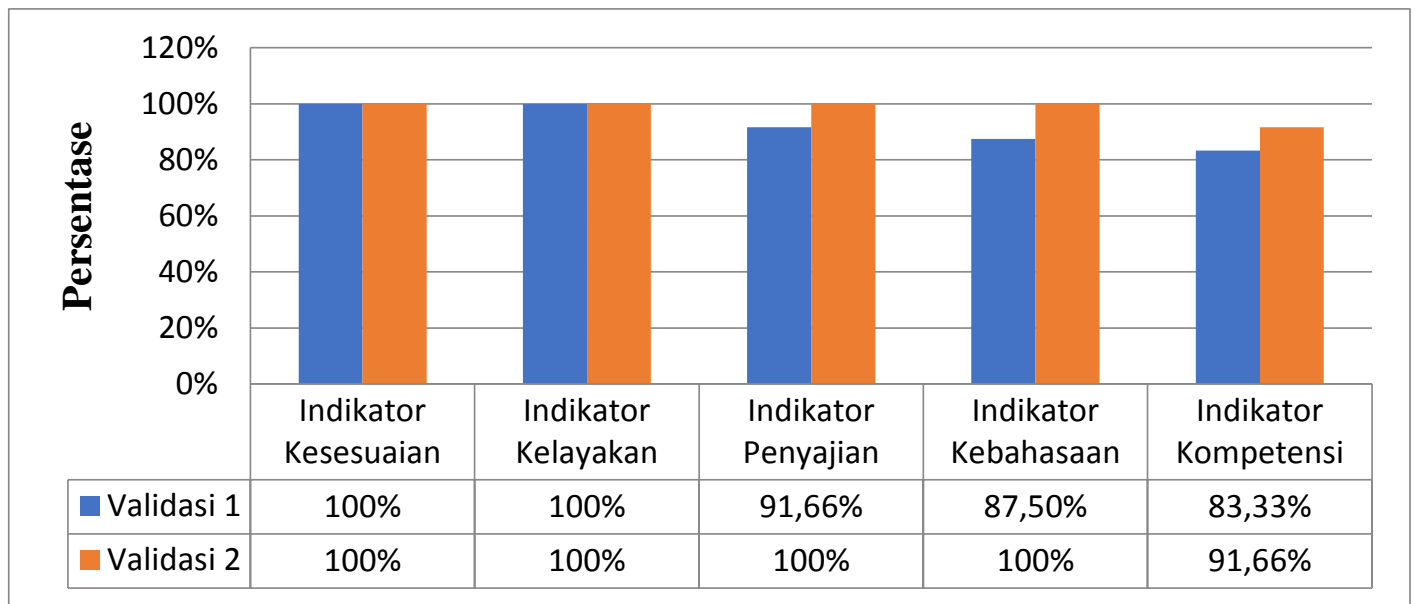

Gambar 3. Hasil Penilaian Media Pembelajaran Komik Strip oleh Dosen Validator Kedua Ahli Materi Validasi Pertama dan Kedua 
Sebagai tolak ukur keberhasilan media yang dikembangkan, dilakukan uji coba lapangan sehingga media pembelajaran komik strip pada pembelajaran matematika materi kecepatan, jarak dan waktu dapat diterima dan dikatakan berhasil. Data mengenai respon peserta didik dan respon guru pada media pembelajaran komik strip dalam bentuk skala likert. Peneliti melakukan uji coba lapangan awal di tiga sekolah di kelas $\mathrm{V}$ yaitu SD Negeri Pecalungan 01, SD Negeri Selokarto 01, dan SD Negeri Gemuh 01 Kabupaten Batang yang bertujuan mengetahui respon guru kelas dan respon peserta didik. Berikut adalah hasil yang didapatkan:

Tabel 1. Nilai Hasil Pretes dan Postes

\begin{tabular}{cccc}
\hline No & Nama Sekolah & Pretes & Postes \\
\hline 1 & SD Pecalungan 01 & 40,36 & 81,07 \\
\hline 2 & SD Selokarto 01 & 39,33 & 65,33 \\
\hline 3 & SD Gemuh 01 & 42,6 & 85,65 \\
\hline
\end{tabular}

Lembar angket respon peserta didik diberikan kepada peserta didik setelah mereka menggunakan media pembelajaran komik strip. Angket respon peserta didik bertujuan untuk mengukur seberapa besar minat peserta didik terhadap media pembelajaran komik strip tersebut.
Angket respon pesera didik terdiri dari 10 soal, setiap nomor soal memiliki jawaban Ya dan tidak. Jika jawaban Ya maka skornya 1 (satu), sedangkan jika jawaban Tidak maka skornya 0 (nol) dengan skor persentase tiap soal. Angket respon pesera didik terdiri dari 10 soal, setiap nomor soal. 
Tabel 2. Angket Respon Peserta Didik Kelas V

\begin{tabular}{ccc}
\hline No & Nama Sekolah & Persentase (\%) \\
\hline 1 & SD Pecalungan 01 & 100 \\
\hline 2 & SD Selokarto 01 & 100 \\
\hline 3 & SD Gemuh 01 & 100 \\
\hline
\end{tabular}

Angket respon guru yang media pembelajaran komik strip diberikan kepada guru bertujuan untuk pembelajaran matematika materi mengetahui respon guru terhadap kecepatan jarak dan waktu.

Tabel 3. Angket Respon Guru Kelas V

\begin{tabular}{ccc}
\hline No & Nama Sekolah & Persentase (\%) \\
\hline 1 & SD Pecalungan 01 & 95 \\
\hline 2 & SD Selokarto 01 & 100 \\
\hline 3 & SD Gemuh 01 & 100 \\
\hline
\end{tabular}

\section{Pembahasan}

Media pembelajaran komik strip dikembangkan peneliti berdasarkan langkah-langkah penelitian dan pengembangan (research and development). Peneliti menggunakan desain pengembangan yang dikemukakan oleh Borg and Gall dalam Sukmadinata (2016: 169-170) , yang terdiri dari beberapa langkah sebagai berikut : (1) Penelitian dan pengumpulan data, (2) Perencanaan,
(3) Pengembangan draf produk, (4) Uji coba lapangan awal, (5) Merevisi hasil uji coba, (6) Uji coba lapangan, (7) Penyempurnaan hasil produk uji coba, (8) Uji pelaksana lapangan, (9) Penyempurnaan produk akhir, (10) Diseminasi dan implementasi. Dari sepuluh langkah tersebut, peneliti mengambil lima langkah dalam proses ini yakni hanya sebatas pada merevisi hasil uji coba. Media pembelajaran komik strip merupakan suatu alternatif 
pengguna media pembelajaran matematika yang dapat membuat peserta didik menjadi tertarik pada pembelajaran matematika serta peserta didik mampu mengikuti dan paham terhadap materi kecepatan, jarak dan waktu dan membantu guru untuk menyampaikan pembelajaran matematika dikelas.

Dengan belajar sambil membaca komik, peserta didik tidak merasa bosan untuk mengikuti pembelajaran dari guru. Media pembelajaran komik strip merupakan media pembelajaran komik dengan alur yang sesuai dengan materi yang akan diajarkan, gambar yang menarik srta menggunakan bahasa yang mudah dipahami peserta didik.

\section{SIMPULAN}

Simpulan dari penelitian pengembangan media pembelajaran komik strip materi kecepatan, jarak dan waktu yaitu media pembelajaran komik strip materi kecepatan, jarak dan waktu dapat digunakan di Sekolah Dasar. Hal ini dibuktikan dengan hasil pretest dan posttestdan angket respon peserta didik serta angket respon guru. Hasil pretest dan posttest dari ketiga SD, yaitu SD Negeri Pecalungan 01 dengan jumlah peserta didik 28 mendapatkan hasil pretest sebesar 40,36 dan hasil posttest 81,07. SD Negeri Selokarto 01 dengan jumlah peserta didik 15 mendapatkan hasil pretest sebesar 39,33 dan hasil posttest 65,33. Dan untuk SD Negeri Gemuh 01 dengan jumlah pesertadidik 23 mendapatkan hasil pretest sebesar 41,74 dan hasil posttest 85,65.

Angket respon peserta didik terhadap media pembelajaran komik strip dari ketiga SD memperoleh persentase keseluruhan sebesar 100\%.Angket respon guru terhadap media pembelajaran komik strip dari ketiga SD memperoleh persentase keseluruhan sebesar 98,33\%.

\section{DAFTAR PUSTAKA}

Arikunto, S. 2014. Evaluasi Program Pendidikan. Jakarta : PT Bumi Aksara.

Arsyad, A. 2017. Media Pembelajaran. Jakarta : Rajawali Pres. 
Daryanto. 2016. Media Pembelajaran. Yogyakarta: Gava Media.

Gumelar. 2011. Comic Making. Jakarta : Indeks.

Prahmana. R.C.I. 2017. Design Research (Teori dan Implementasinya: Suatu Pengantar). Depok : PT. Raja Gravindo Persada.

Sugiyono. 2015. Metode Penenlitian Kuantitatif, Kualitatif dan R\&D. Bandung : Alfabeta.

Sukmadinata. 2016. Metode Penelitian pendidikan. Bandung : PT Remaja Rosdakarya.
Susanto, Ahmad. 2013. Teori Belajar \& Pembelajaran di Sekolah Dasar. Jakarta : Prenadamedia Group.

Suyono, 2016. Belajar dan Pembelajaran. Bandung : PT. Remaja Rosdakarya .

Novitasari, Diana Lela. (2016). Pengembangan Media Komik Cerita Anak Untuk meningkatkan Keterampilan Menulis Narasi Peserta didik Kelas IV SDN 1 Ngawen Kabupaten Blora [ skripsi ]. Semarang : Universitas Negeri Semarang. 